\title{
Studies on The Allelopathic Effects of Tithonia rotundifolia on the Germination and Seedling Growth of Some Legumes and Cereals
}

\author{
Olutobi Otusanya ${ }^{1} \&$ Olasupo Ilori ${ }^{2}$ \\ ${ }^{1}$ Botany Department, Obafemi Awolowo University, Ile-Ife, Nigeria \\ ${ }^{2}$ Biology Department Adeyemi College of Education, Ondo, Nigeria \\ Correspondence: Olasupo Ilori, Biology Department Adeyemi College of Education, Ondo, Nigeria. E-mail: \\ olasupoilori@yahoo.com
}

Received: October 4, 2013 Accepted: October 22, 2013 Online Published: November 15, 2013

doi:10.5539/ijb.v6n1p38

URL: http://dx.doi.org/10.5539/ijb.v6n1p38

\begin{abstract}
The study investigated the allelopathic effects of Tithonia rotundifolia on the germination and growth of two legumes (Vigna unguiculata and Glycine max) and two cereals (Zea mays and Sorghum bicolor). This was with a view to determining the susceptibility of these test crops to allelochemicals. The germination studies were carried out by raising seedlings in Petri-dishes which had been lined with Whatman No. 1 filter paper. Ten millilitres of $100 \%, 75 \%, 50 \%$ and $25 \%$ concentrations of the methanolic or water extract solutions were used for the treatments while distilled water served as control. Germination and growth analyses were carried out according to standard methods. The data obtained were analysed by Factorial Analysis of Variance (ANOVA) to determine significant $(\mathrm{P}<0.05)$ effects. The germination and growth of the juvenile seedlings of all the test crops were significantly inhibited by the methanolic and water extracts dose dependently. However, the methanolic extracts had a more pronounced inhibitory effect on these parameters. The study concluded that the methanolic extracts were more phytotoxic and had higher inhibitory effects on the parameters than the water extracts. Also, it was observed that the response of plants to allelochemical toxicity was dependent on plant species.
\end{abstract}

Keywords: allelopathic, methanolic extract, water extract, Tithonia rotundifolia, legumes, cereals

\section{Introduction}

The phenomenon of allelopathy has received increasing attention as a means of explaining vegetation patterns in plant communities (Miller, 1996). According to Inderjit et al. (1999), allelopathy may occur in all environments and should be considered as a part of community interaction. Kohli et al. (1998) and Singh et al. (2001) opined that allelopathy plays an important role in many agro-ecosystems. A large number of plants impose inhibitory effects on the germination and growth of neighbouring or successional plants by releasing allelopathic chemicals into the soil, either as exudates from living tissues or by decomposition of plant residues (Rice, 1984; Narwal, 1999; Alam \& Islam, 2002; Khan et al., 2009). Bendall (1975) studied water and ethanol extracts and residues in soil and concluded that an allelopathic mechanism might be involved in the exclusion of some annual thistle (Carduus crispus L.), pasture and crop species in areas infested with Cirsium arvense (L) Scop. According to Stachon and Zimdal (1980), C. arvense litter reduced the growth of Amaranthus retroflexus L. and Setaria viridus L. more than that of cucumber (Cucumis sativus L.) or barley (Hordeum vulgare L.) in greenhouse experiments. They also observed that high densities of $C$. arvense reduced the incidence of annual weeds growing in the vicinity of $C$. arvense. Khan et al. (2009) stated that aqueous extracts of Eucalyptus camaldulensis L. inhibited seed germination, fresh and dry weight of wheat seedlings. Rawat et al. (2002) reported that aqueous extract of the root of Helianthus annus delayed and inhibited the germination and seedling growth of linseed (Linum usitatissium L.) and mustard (Brassica juncea L.) Aqueous extracts from the leaves of Helianthus tuberosus L. Xanthium occidentale, Lactuca sativa and Cirsum japonica all in the Asteraceae family inhibited the root growth of Lucerne (Chon et al., 2003). Ilori et al. (2007) observed that the radical growth of Oryza sativa was inhibited by aqueous extract of T. diversifolia. Otusanya et al. (2007) reported that the growth of Amaranthus cruentus was inhibited by aqueous extract of T. diversifolia. Javed and Asghari (2008) reported that the leaf extract of Helianthus annus inhibited the rate of germination of wheat seedlings.

In Nigeria, Tithonia rotundifolia is a widespread species having colonized roadsides, waste places, fallow land 
and disturbed open spaces like abandoned construction sites etc. and displacing traditional weedy species like Chromolaena odorata and Panicum maximum (Adebowale \& Olorode, 2005). The plant associates with common crops like vegetables, cassava, yam, rice, sorghum, soyabean e.t.c. and becomes a dominant plant where it is present (Tongma et al., 1998). Cowpea (Vigna unguiculata (L.) Walpers) and Soybean (Glycine max (L.) Merr.) which belong to the family Fabaceae are economically significant legumes in the tropics. Maize (Zea mays L.) and Sorghum (Sorghum bicolor (L.) Moench) are annual grasses belonging to the family Poacea. $Z$. mays L. is one of the most important cereal crops growing in the world. It is used as food for human consumption as well as food grain for animals (Moussa, 2001). S. bicolor (L.) Moench is a drought resistant cereal important for grain, forage and bioethanol production (Aishah et al., 2011). Considering the effects of Tithonia species on associated crops, the objectives of this work was to determine the effects of water and methanolic extracts of fresh shoots of $T$. rotundifolia on the germination, growth parameters (plumule and radicle lengths) and yield parameters (fresh and dry weights of plumule and radicle) of juvenile seedlings of $V$. unguiculata, G. max, Z. mays and S. bicolor.

\section{Materials and Methods}

\subsection{Study Area}

This study was conducted at the Botany Department of the Obafemi Awolowo University (O. A. U.), Ile-Ife, Osun State, Nigeria, Latitude $07^{\circ} 30^{\prime} \mathrm{N}-07^{\circ} 35^{\prime} \mathrm{N}$ and Longitude $04^{\circ} 30^{\prime}-04^{\circ} 40^{\prime} \mathrm{E}$.

\subsection{Plant Materials}

The plant materials that were utilized in this study are the seeds of the following plants Tithonia rotundifolia (Miller) S. F. Blake, Vigna unguiculata L.Walp, Glycine max L. Merr., Zea mays L. and Sorghum bicolor (L.) Moench. The seeds of the test crops (Vigna unguiculata, Glycine max, Zea mays, and Sorghum bicolor) were collected from IITA (International Institute of Tropical Agriculture) Ibadan. T. rotundifolia seeds were collected along Road 20 at the Senior Staff Quarters of O. A. U., Ile Ife.

\subsection{Germination Experiment}

Preparation of extracts for the different treatments was carried out according to the modified method of Qasem and Abu - Irmaileh (1985). The extract solution (100\%) was diluted appropriately with water to give $75 \%, 50 \%$, and $25 \%$ concentrations of the aqueous extracts while distilled water served as control. Petri-dishes were thoroughly washed and oven dried. The seeds of the different test plants were selected randomly on the basis of uniformity of size and the seeds were then soaked for five minutes separately in 5\% sodium hypochlorite to prevent fungal infection. Thereafter they were rinsed for about five minutes in running tap water. Ten of the seeds were placed in each of the clean oven dried Petri-dish which had been lined with a Whatman No. 1 filter paper. The filter paper in each of the Petri-dishes allocated to the control was moistened with ten millilitres of distilled water while that of the Petri-dishes allocated to the other treatments were moistened with ten millilitres of the appropriate concentration of the extracts. The Petri-dishes were incubated at room temperature for two weeks. Emergence of one millimetre of the radicle was used as the criterion for germination. Measurements of germination, plumule and radicle lengths, fresh and dry weights were carried out using standard methods.

\subsection{Statistical Analysis}

The data obtained were analysed by factorial Analysis of Variance (ANOVA) to determine significant $(\mathrm{P}<0.05)$ effects.

\section{Results}

The percentage germination of the control seeds of the test crops was higher than that of the seeds treated with the different extracts (Figure 1). In most cases the percentage germination increased as extracts concentration decreased. There was significant reduction of the germination of the seeds by all the concentrations of FME and FWE at $\mathrm{P}<0.05$. Seedlings of the test crops in the control had plumule and radicle lengths that were significantly higher than those of the seedlings in all the extract regimes and these plumule and radicle lengths reduced with increase in the concentration of the methanolic extracts and water extracts (Figures $2 \& 3$ ). The control seedlings of all the test crops had plumule fresh weight that was significantly higher than that of the seedlings in both the FME and FWE regimes (Figure 4). The plumule fresh weights of the seedlings in all the extract regimes increased with decrease in the concentration of the extracts. The radicle fresh weight of $V$. unguiculata and $S$. bicolor seedlings in the $25 \%$ and $50 \%$ FWE was almost equivalent or slightly higher than that of the control seedlings while the other extracts inhibited the radicle fresh weight of these seedlings. In the case of the G. max and Z. mays seedlings, the methanolic extract was more phytotoxic than the water extracts and the radicle fresh weight was inhibited by all the extracts (Figure 5). The plumule dry weight of the control $V$. unguiculata seedlings was higher 
than that of the seedlings in all the extract regimes while that of the seedlings in the $75 \%$ and $100 \%$ extract regimes were almost equivalent and lower than that of the $25 \%$ extracts regime. Also, the $25 \%$ FWE seedlings of Z. mays had the same plumule dry weight with that of the control while that of the S. bicolor seedlings in the $25 \%$ FME was lower than that of the seedlings in the 50\% FME regime. In the case of the G. $\max$, the plumule dry weight of the seedlings in the 100\% FME and FWE regimes was much lower than that of the control, FME and FWE seedlings (Figure 6). V. unguiculata, G. max and Z. mays seedlings in the control regime had radicle dry weight that were higher than those of the seedlings in all the extract regimes. However, the radicle dry weight of the control $S$. bicolor seedlings was equivalent to that of the $25 \% \mathrm{FWE}$ seedlings (Figure 7). Interactions of extracts $\mathrm{x}$ crops, crop $\mathrm{x}$ extract concentrations were found significant for all the parameters except plumule dry weight (Table 1).

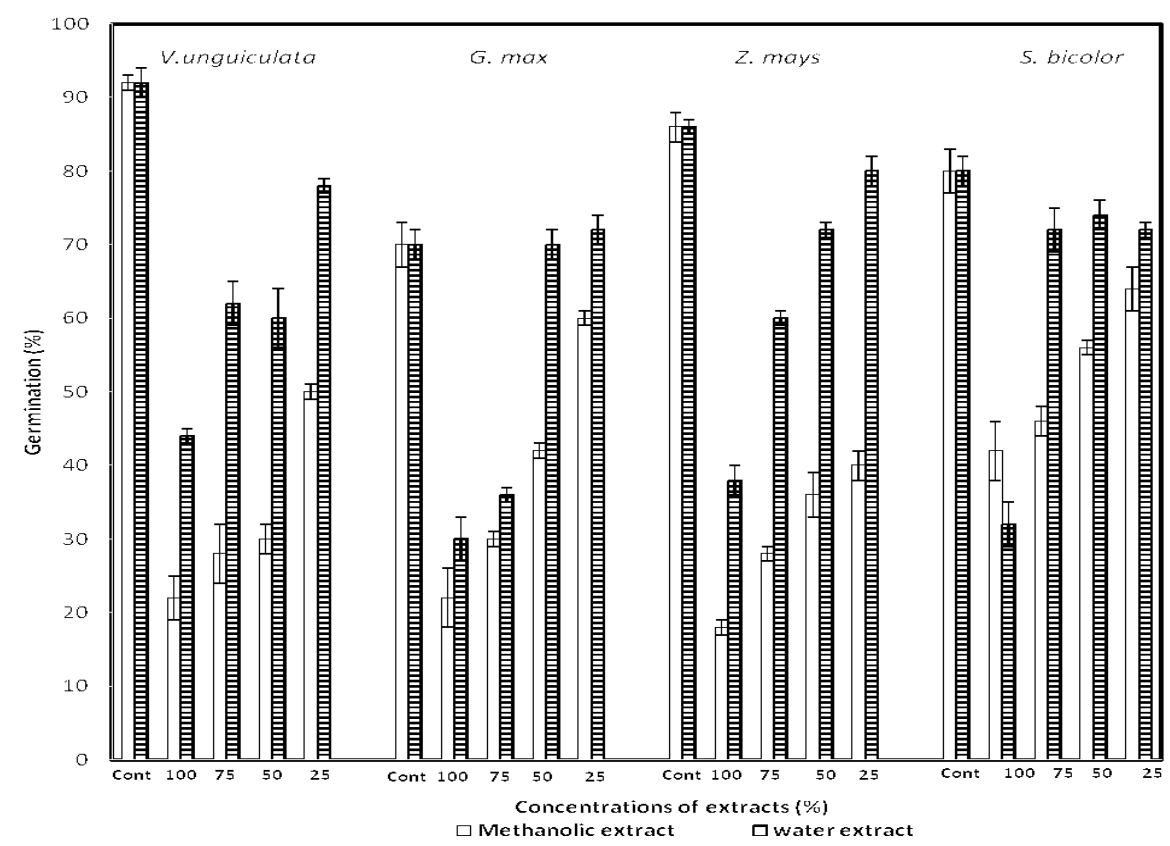

Figure 1. Effect of the methanolic extracts and water extracts of the fresh shoots of T. rotundifolia on the germination of the test crops. Capped bars indicate standard errors 


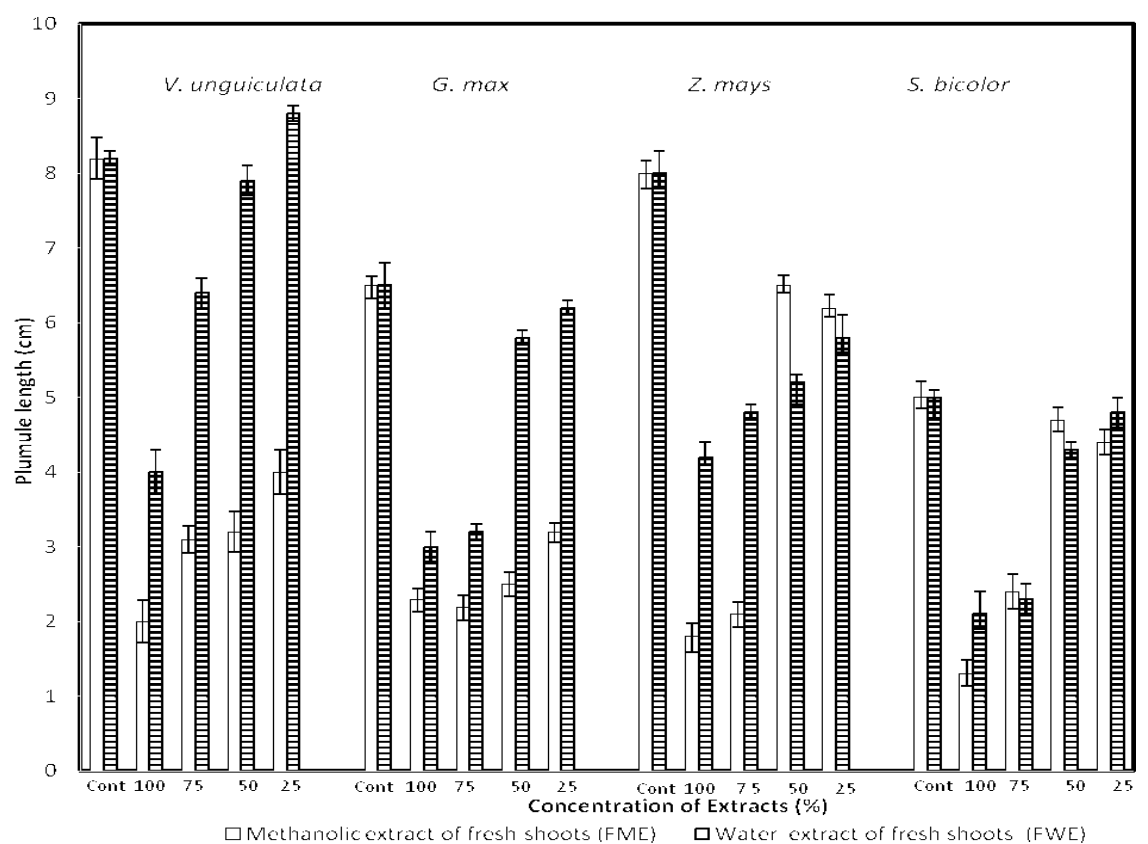

Figure 2. Effect of the methanolic and water extracts of the fresh shoots of T. rotundifolia on the plumule length of the test crops. Capped bars indicate standard errors

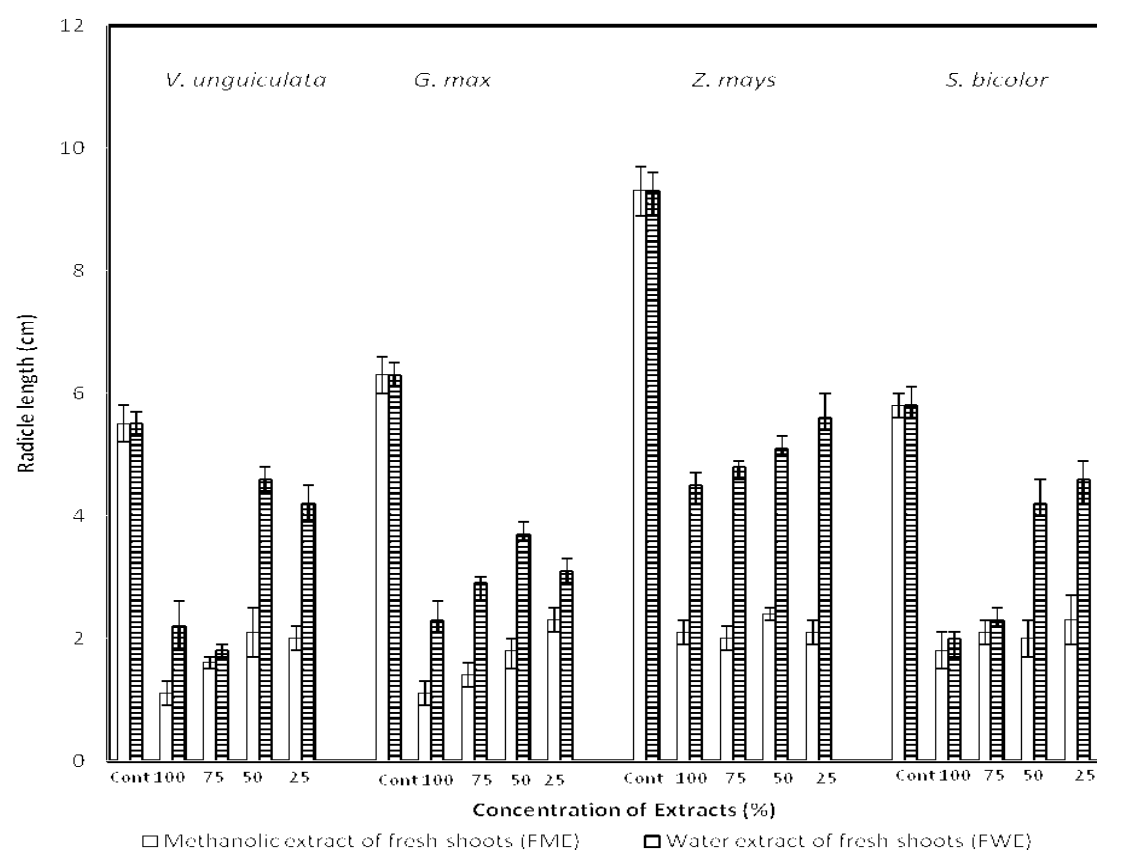

Figure 3. Variation in the radicle length of the test crops treated with the methanolic extracts and water extracts of the fresh shoots of T. rotundifolia. Capped bars indicate standard errors 


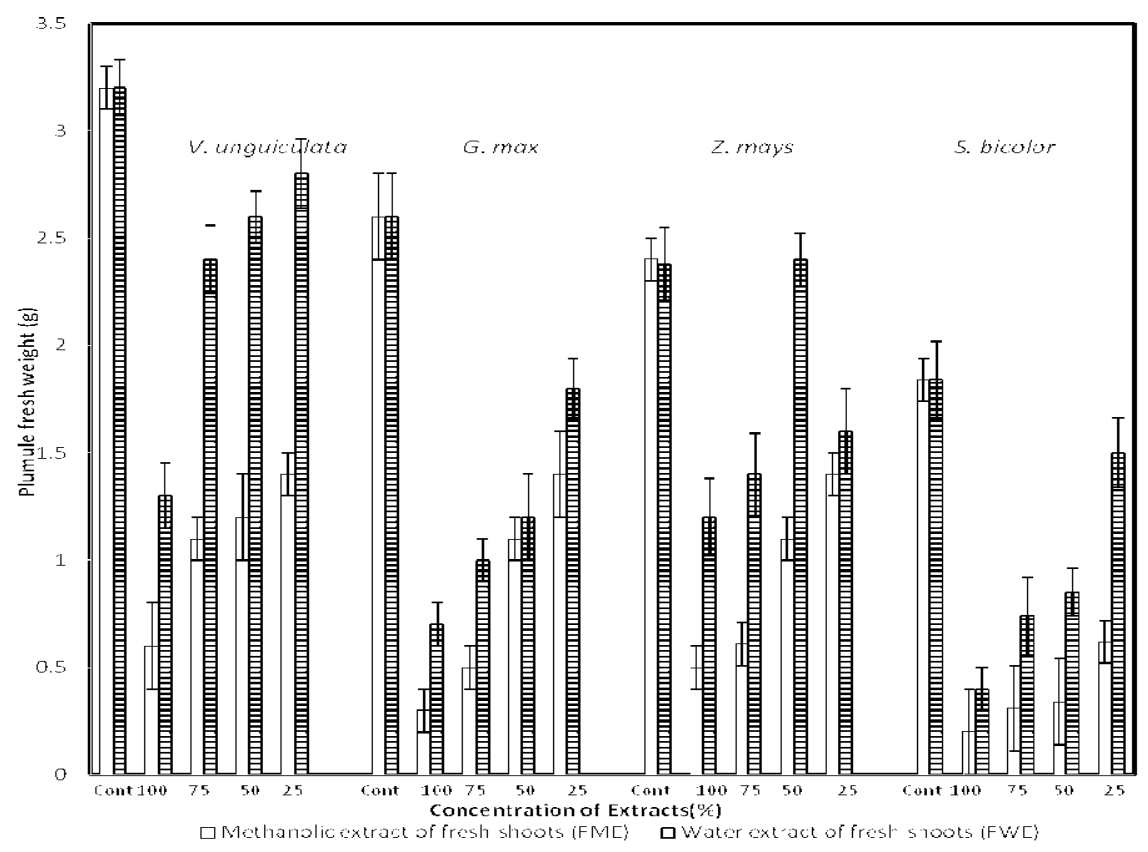

Figure 4. Variation in the plumule fresh weight of the test crops treated with the methanolic extracts and water extracts of the fresh shoots of T. rotundifolia. Capped bars indicate standard errors

\section{Discussion}

According to Leu et al. (2002) and Inderjit and Duke (2003), allelopathy in natural and agricultural ecosystems is receiving increasing attention because allelochemicals significantly reduce the growth of other plants and the yields of crop plants. Allelochemicals are secondary plant products or waste products generated by the plant's main metabolic pathways which are released into the environment in appreciable quantities via root exudates, leaf leachates, roots and other degrading plant residues (Putnam, 1988). These chemicals have harmful effects on crops in the ecosystem resulting in the reduction and delayed germination, seedling mortality and reduction in growth and yield (Herro \& Callaway, 2003). The process of seed germination is a crucial stage in plant growth. During germination, biochemical changes take place, which provides the basic framework for subsequent growth and development (Khan et al., 2009). According to Bhownmik and Inderjit (2003), allelochemicals can affect the establishment or regeneration of population by affecting seed germination. These authors were of the opinion that increasing germination can enhance the competitive ability of a plant species for both above-ground and underground resources.

The water and methanolic extracts from T. rotundifolia had significant inhibitory effect on the germination of the seeds of all the test crops in this study.This observation agreed with the findings of Inderjit and Dakshini (1994) who reported that the water extracts from the roots of Pluchea lanceolata in the family Asteraceae inhibited the germination of tomato and mustard. The water extracts from tissues of Helianthus annus were also observed to inhibit germination of Solanum nigrum (Sedigheh et al., 2010). Rawat et al. (2002) found that the aqueous extract of the root of Helianthus annus delayed and inhibited the germination and seedling growth of linseed (Linuna usitatissium L.) and mustard (Brassia Juncia L.). Nandal and Dhillon (2005) reported that the aqueous extracts of poplar leaves adversely affected the germination and seedling growth of some wheat varieties at high extract concentrations. Mulatu et al. (2006) reported that aqueous extract of Parthenium hysterophorus leaves and flower inhibited seed germination of lettuce. Preliminary investigations have revealed that the aqueous extract from the leaves of $T$. diversifolia retarded the germination and the radicle growth of Oryza sativa, Amaranthus cruentus, Capsicum annum and Lycopersicon esculentum (Ilori et al., 2007; Otusanya et al., 2007; Otusanya et al., 2008). Khan et al. (2009) reported that the reduction in germination counts of wheat became more pronounced with increasing levels of Eucalyptus camaldulensis aqueous extract concentration. Javed and Asghari (2008) also found that the leaf extract of Helianthus annus inhibited the rate of germination of wheat seedlings. A related work by Arshad (2011) showed that the water and methanolic extracts of Withania somnifera 
markedly suppressed the germination, root and shoot growth of Parthenium hysterophorus.

The growth of the plumule and radicle of the water and methanolic extracts treated seedlings of the test crops were significantly inhibited at $\mathrm{P}<0.05$. The inhibition of the growth of the radicle of G. max and Z. mays were more pronounced than that of the plumule growth. These results corroborates the earlier findings of several other workers such as Chou and Kuo (1986), Alam (1990), Zackrisson and Nilsson (1992) and Munir and Tawaha (2002) who all asserted that root growth was more sensitive to the increasing concentration of plant aqueous extracts in comparison to the shoot growth. The more accentuated effect of the allelochemical on the roots might be due to their closer contact with the leachates or extracts especially when maintained on filter/germination paper (Chung et al., 2001). Rahman (1998) reported that aqueous extract derived from the inflorescence, stem, and leaves of Parthenium hysterophorus L. inhibited the growth of radicle and plumule of Cassia sophera Linn. Florentine et al. (2006) observed that allelopathy is characterized by reduction in plants emergence or growth, reducing their performance in the association. A similar result was reported by Kushima (1998) who stated that there was an inhibition of the growth of the plumule length of tomato seedlings by the application of leachate from water melon seeds. James and Bala (2003) found that dried mango leaf powder significantly inhibited the sprouting of purple nutsedge tubers while Yang et al. (2006) reported that its aqueous extract inhibited the germination and growth of some crops. Also, the results in this study was consistent with the finding of Ilori et al. (2007) who stated that the radicle growth of Oryza sativa was inhibited by the aqueous extract of T. diversifolia (a close relative of the donor plant). This retardation of the juvenile seedling growth of the target crops was observed to increase significantly with increasing extract concentrations. This was consistent with the work of Khan et al. (2009) who reported that the inhibitory effects of aqueous extracts of Eucalyptus camaldulensis L. on germination and seedling growth (fresh and dry weight) of wheat were increased as the extract concentration increased. A similar result was obtained by Swapnal and Badruzzaman (2010) on the allelopathic effect of Croton bonplandianum Baill. weed on seed germination and seedling growth of crop plants. They reported that the root length, shoot length of Melilotus alba Medik., Vicia sativa L. and Medicago hispida Gaertn. decreased progressively when the plants were exposed to increasing concentration of the extract of Croton bonplandianum Baill. Khan et al. (2009) from their study of the effect of Eucalyptus extracts on twelve varieties of wheat concluded that the variation in germination of different varieties might be due to variation of the genetics of these twelve varieties. Likewise, it was observed in this study that the response of plants to allelochemicals toxicity was found to be dependent on plant species. The most affected crops were G. max and Z. mays for radicle fresh and dry weights and $V$. unguiculata for germination.

\section{Conclusion}

It can be summarized from the results of this study that both the water and methanolic extracts at any concentration inhibited the germination, growth and ultimately the yield of the test crops. The methanolic extract was more phytotoxic than the water extracts. The extent of the inhibition by the water and methanolic extracts followed this order: $100 \%>75 \%>50 \%>25 \%$. This affirmed the fact that the response of the target crops was extract concentration dependent. In conclusion, the effectiveness of these extracts on the germination and growth of the crops in this study showed that the presence of $T$. rotundifolia would negatively affect the neighboring or successional crop plants. 


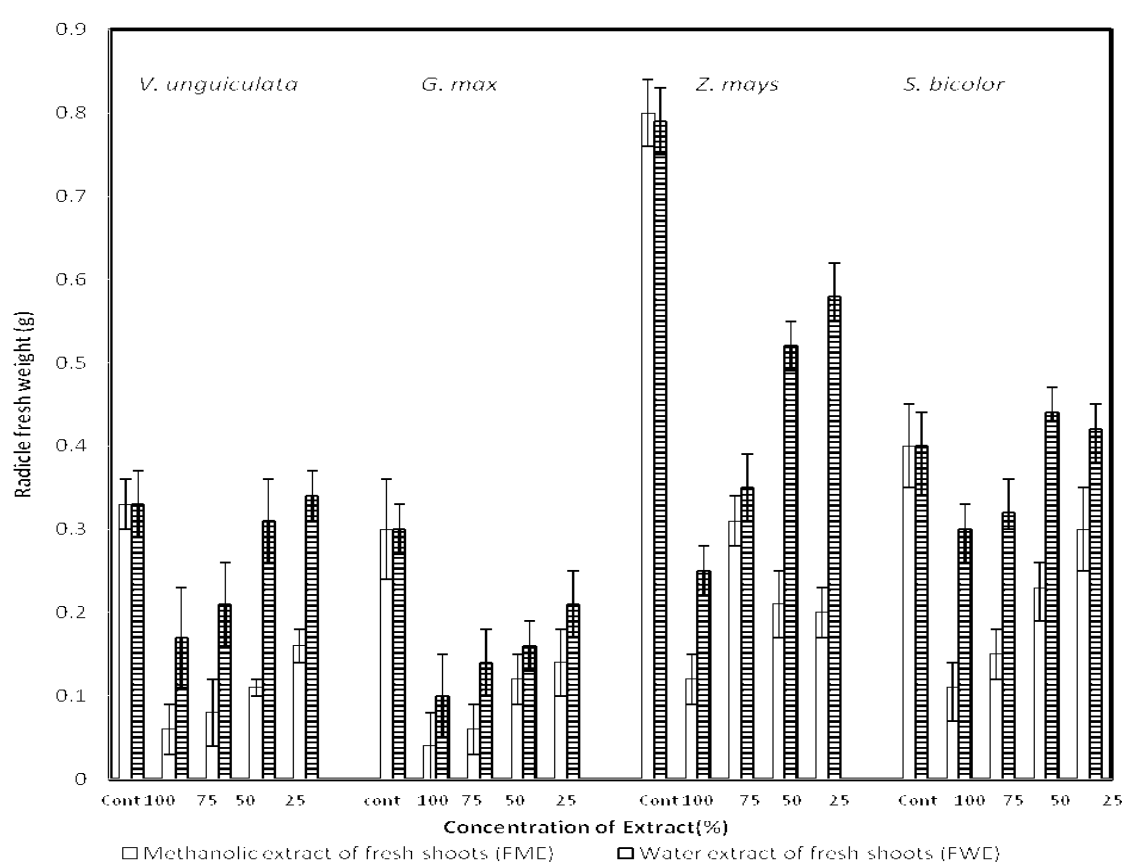

Figure 5. Radicle fresh weight of the test crops as affected by the methanolic and water extracts of the fresh shoots of T. rotundifolia. Capped bars indicate standard errors

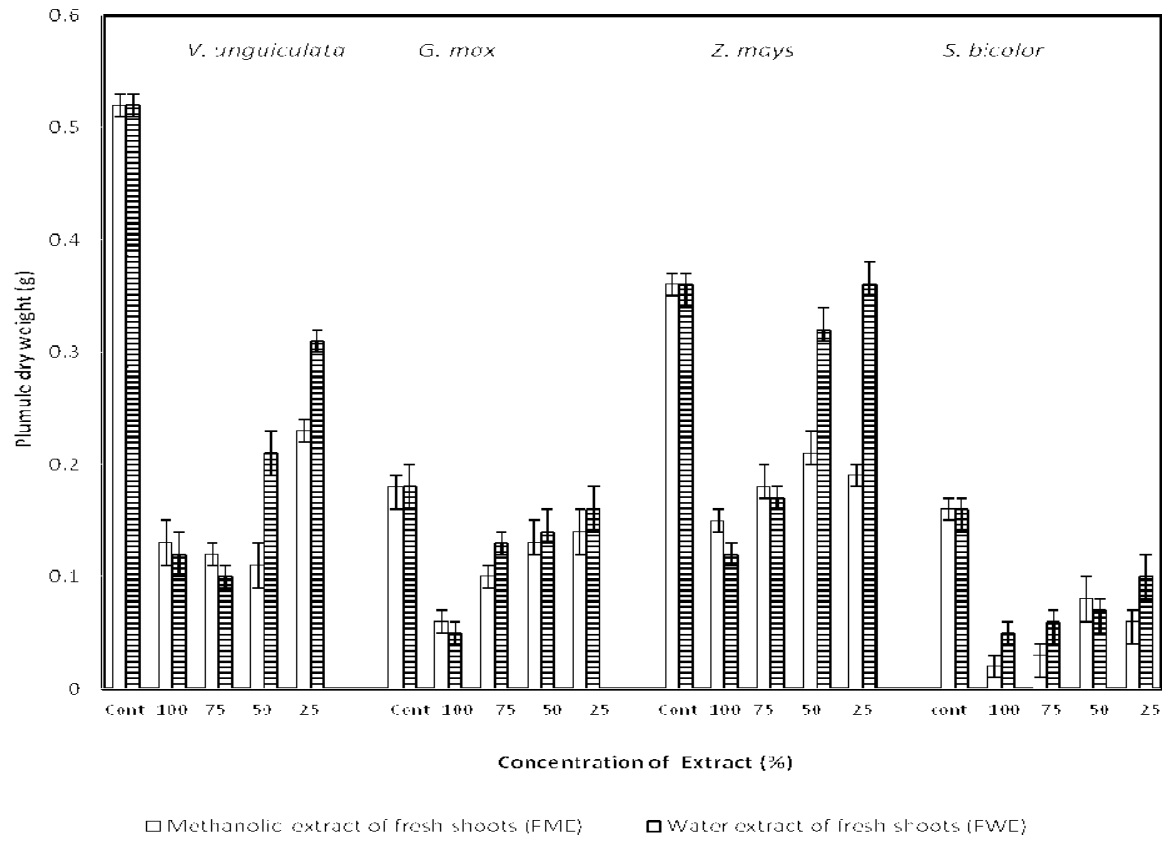

Figure 6. Plumule dry weight of the test crops as affected by the methanolic and water extracts of the fresh shoots of T. rotundifolia. Capped bars indicate standard errors 


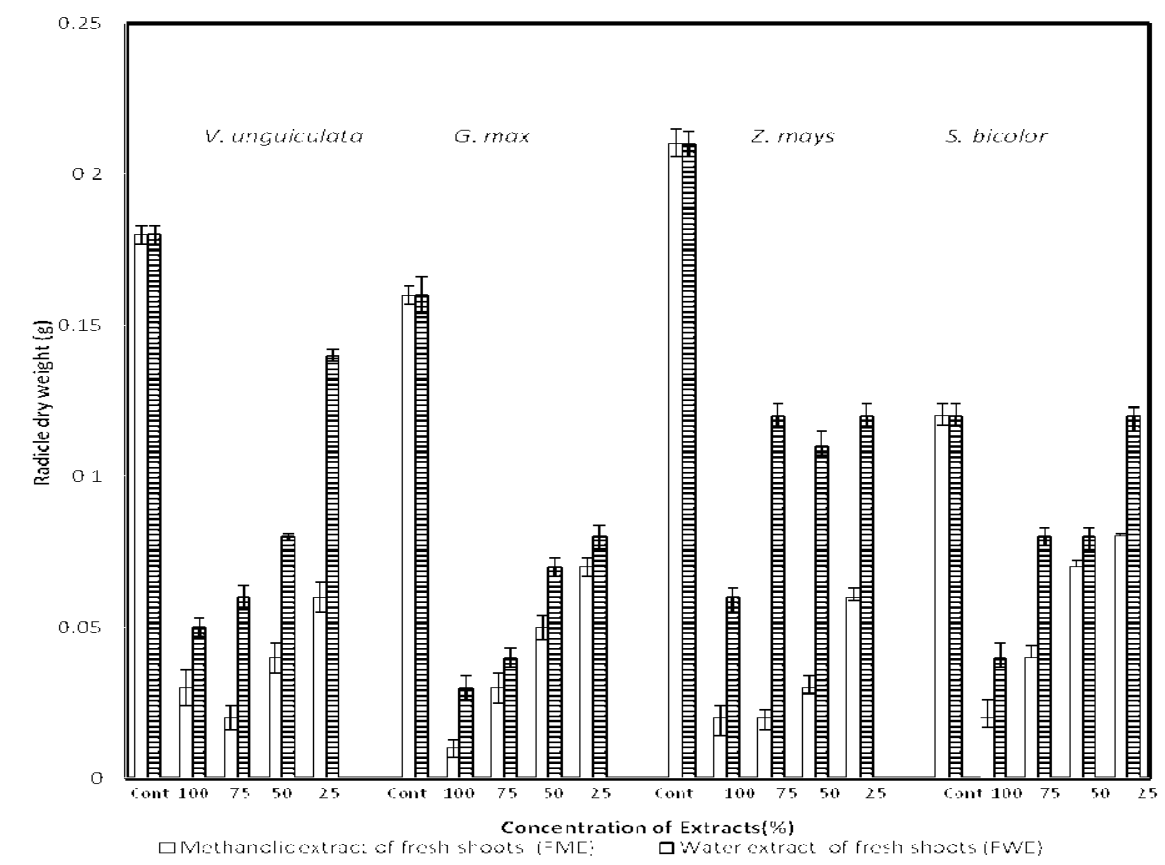

Figure 7. Radicle dry weight of the test crops as affected by the application of the methanolic extracts and water extracts of the fresh shoots of T. rotundifolia. Capped bars indicate standard errors

Table 1. Results of analysis of variance of the traits determined

\begin{tabular}{ccccccccc}
\hline Source & df & $\begin{array}{c}\text { Germination } \\
\text { percentage }\end{array}$ & $\begin{array}{c}\text { Plumule } \\
\text { length }\end{array}$ & $\begin{array}{c}\text { Radicle } \\
\text { length }\end{array}$ & $\begin{array}{c}\text { Plumule } \\
\text { fresh weight }\end{array}$ & $\begin{array}{c}\text { Radicle } \\
\text { fresh } \\
\text { weight }\end{array}$ & $\begin{array}{c}\text { Plumule } \\
\text { dry weight }\end{array}$ & $\begin{array}{c}\text { Radicle dry } \\
\text { weight }\end{array}$ \\
\hline Crops(C) & 3 & $* *$ & $* *$ & $* *$ & $* *$ & $* *$ & $* *$ & $* *$ \\
Extracts(E) & 1 & $* *$ & $* *$ & $* *$ & $* *$ & $* *$ & ns & $* *$ \\
Conc. & 4 & $* *$ & $* *$ & $* *$ & $* *$ & $* *$ & $* *$ & $* *$ \\
C x E & 3 & $* *$ & $* *$ & $* *$ & $* *$ & $* *$ & ns & $* *$ \\
C x Conc. & 12 & $* *$ & $* *$ & $* *$ & $* *$ & $* *$ & $* *$ & $* *$ \\
E x Conc. & 4 & $* *$ & $* *$ & $* *$ & $* *$ & $* *$ & $n s$ & $* *$ \\
C x E x & 12 & $* *$ & $* *$ & $* *$ & $* *$ & $* *$ & $n s$ & $* *$ \\
Conc & & & & & & & & $*$
\end{tabular}

** $\mathrm{P}<0.05$, df, degrees of freedom. Conc., concentration

\section{References}

Adebowale, A., \& Olorode, O. (2005). An overview of the invasive potential of Tithonia species (Asteraceae) in Nigeria. Science Focus, 10(3), 65-69.

Aishah, S., Saberi, H. A. R., Halim, R. A., \& Zaharah, A. R. (2011). Yield responses of forage sorghums to salinity and irrigation frequency. Africa Journal of Biotechnology, 10(20), 4114-4120. Retrieved from http://www.ajol.info/index.php/ajb/article/view/93588

Alam, S. M., \& Islam, E. U. (2002). Effect of aqueous extract of leaf stem and root of nettleleaf goosefoot and $\mathrm{NaCl}$ on germination and seedling growth of rice. Pacific Journal of Science and Technology, 1(2), 47-52.

Alam, S. M. (1990). Effect of wild plant extract on germination and seedling growth of wheat. Rachis, 9, 12-13. Retrieved from http://www.cabdirect.org/abstracts/19916776706.html

Arshad, J., Shazia, S., \& Sobiya, S. (2011). Management of Parthenium hysterophorus (Asteraceae) by Withania 
somnifera (Solanaceae). Natural Product Research, 25(4), 407-416. http://dx.doi.org/10.1080/14786419.2010.483230

Bendall, G. M. (1975). The allelopathic activity of California thistle (Cirsium arvense) in Tasmaria. Weed Research, 15, 17-81.

Bhownmik, P. C., \& Inderjit, C. (2003). Challenges and opportunities in implementing Allelopathy for natural weed management. Crop Protection, 22, 661-671. http://dx.doi.org/10.1016/S0261-2194(02)00242-9

Chon, S. U., Kin, Y., \& Kee, J. C. (2003). Herbicidal potential and quantification of causative allelochemicals from several compositae weeds. European Weed Research Society. Weed Research, 43, 444-450. http://dx.doi.org/10.1046/j.0043-1737.2003.00361.x

Chou, C. H., \& Kuo, Y. L. (1986). Allelopathic research in subtropical vegetation in Taiwan HI. Allelopathic exclusion of understory species by Leucaena lencocephala. Journal of Chemical Ecology, 12, 1431-1448. http://dx.doi.org/10.1007/BF01012362

Chung, I. M., Ahn, J. K., \& Yun, S. J. (2001). Identification of allelopathic compounds from rice (Oryza sativa L.) straw and their biological activity. Canadian Journal of Plant Science, 81, 815-819. http://dx.doi.org/10.4141/P00-191

Florentine, S. K., Westbrooke, M. E., Gosney, K., Ambrose, G., \& O’ Keefe, M. (2006). The arid lands invasive weed Nicotiana glauca R. Graham (Solanaceae): Population and soil seed bank dynamics, seed germination patterns and seedling response to flood and drought. Journal of Arid Environment, 66, 218-230. http://dx.doi.org/10.1016/j.jaridenv.2005.10.017

Herro, J. L., \& Callaway, R. M. (2003). Allelopathy and exotic plant invasion. Plant and soil, 256, 29-39. http://dx.doi.org/10.1023/A:1026208327014

Ilori, O. J., Otusanya, O. O., \& Adelusi, A. A. (2007). Phytotoxic effects of Tithonia diversifolia on germination and growth of Oryza sativa. Research Journal of Botany, 2(1), 23-32. http://dx.doi.org/10.3923/rjb.2007.23.32

Indergit, M., \& Darkshini, K. M. M. (1994). Allelopathic effect of Pluchea lanceolata (Asteraceae) on characteristics of four soils and tomato and mustard growth. American Journal of Botany, 81, 799-804. http://dx.doi.org/10.2307/2445760

Indergit, M., Darkshini, K. M. M., \& Chester, L. (1999). Principle and practices in plant ecology. In Foy (Eds.), Allelochemical Interactions.

Inderjit, M., \& Duke, S. O. (2003). Ecophysiological aspects of allelopathy. Planta, 217, 529-539. http://dx.doi.org/10.1007/s00425-003-1054-z

James, J. F., \& Bala, R. (2003). Allelopathy: How plants suppress other plants. The Hort. Sc. Depart. Inst. Food Agric. Sci. Univ. Florida.

Javed, K., \& Asghari, B. (2008). Effects of sunflower (Helianthus annuus L.) extracts on wheat (Triticum aestivum L.) and physicochemical characteristics of soil. African Journal of Biotechnology, 7(22), 4130-4135.

Khan, M. A., Hussain, I., \& Khan, E. A. (2009). Allelopathic effects of Eucalyptus (Eucalyptus Camaldulensis L.) on germination and seedling growth of wheat (Triticum aestivum L.) Pakistan Journal of Weed Science Research, 15(2-3), 131-143.

Kohli, R. K., Batish, D., \& Singh, H. P. (1998). Allelopathy and its implications in agroecosystems. Journal of Crop Production, 1, 169-202. http://dx.doi.org/10.1300/J144v01n01_08

Kushima, M., Hideo, K., Seiji, K., Shosuke, Y., Yamada, K., Yokotani, T., \& Koji, H. (1998). An allelopathic substance exuded from germinating water melon seeds. Plants Growth Regulation, 25, 1-4. http://dx.doi.org/10.1023/A:1005907101778

Leu, E., Krieger-Liszkay, A., Goussias, C., \& Gross, E. M. (2002). Polyphenolic allelochemicals from the aquatic angiosperm Myriophyllum spicatum inhibit photosystem II. Plant Physiology, 130, 2011-2018. http://dx.doi.org/10.1104/pp.011593

Miller, D. A. (1996). Allelopathy in forage crop systems. Agronomy Journal, 88, 854-859. http://dx.doi.org/10.2134/agronj1996.00021962003600060003x

Moussa, H. R. (2001). Physiological and biochemical studies on the herbicide (Dual) by using radiolabelled 
technique. Ph.D. Thesis. Faculty of Science Ain-Shams University.

Mulatu, W., Gezahegn, B., \& Befekadu, B. (2006). Allelopathic effect of Parthenium hysterophorus extract on seed germination and seedling growth of lettuce. Tropical Science, 45(4), 159-162.

Munir, A. T., \& Tawaha, A. R. M. (2002). Inhibitory effects of aqueous extracts of black mustard on germination and growth of lentil. Pakistan Journal of Agronomy, 1(1), 28-30. http://dx.doi.org/10.3923/ja.2002.28.30

Nandal, \& Dhillon, A. (2005). Allelopathic effects of poplar (Populus deltoides Bartr Ex Marsh): an assessment on the response of wheat varieties under laboratory and field conditions. Proc. Fourth World Congress on Allelopathy 21-26 August 2005. Charles Sturt University, Wagga, NSW, Australia.

Narwal, S. S. (1999). In Enfield (Ed.), Allelopathy update, basic and applied aspects (Vol. 2, pp. 203-54). Science Publishers Inc: New Hampshire.

Otusanya, O. O., Ikonoh, O. W., \& Ilori, O. J. (2008). Allelopathic potentials of Tithonia diversifolia (Hemsl) A. Gray: Effect on the germination, growth and chlorophyll accumulation of of Capsicum annum L. and Lycopersicon esculentum Mill. International Journal of Botany, 4(4), 471-475. http://dx.doi.org/10.3923/ijb.2008.471.475

Otusanya, O. O., Ilori, O. J., \& Adelusi, A. A. (2007). Allelopathic effect of Tithonia diversifolia on germination and growth of Amaranthus cruentus Linn. Research Journal of Environmental Sciences, 1(6), 285-293. http://dx.doi.org/10.3923/rjes.2007.285.293

Putnam, A. R. (1988). Allelochemicals from plants as herbicides. Weed Technology, 2, 510-518. Retrieved from http://www.jstor.org/stable/3987390

Rahman, A. (1998). Allelopathic potential of Pathenium hysterophorus L on germination, growth, and dry matter production in Cassia sopheras L. Bionature, 18(1), 17-20.

Rawat, L. S., Rawat, D. S. K., Narwal, S. S, Palaniraj, R., \& Sati, S. C. (2002). Allelopathic effects of aqueous extracts of sunflower (Helianthus annus L.) root on some winter oil seed crop. Geobies (Jodhpur), 29(4), 225-228.

Rice, E. L. (1984). Allelopathy (2nd Ed.) (p. 422). New York, U.S.A.: Academic Press.

Sedigheh, S., Aptin, R., \& Zoheir, Y. A. (2010). Allelopathic effect of Helianthus annus (sunflower) on Solanum nigrum (black nightshade) seed germination and growth in laboratory condition. Journal of Horticultural Science and Ornamental Plants, 2(1), 32-37.

Singh, H. P., Kohli, R. K., \& Batish, D. R. (2001). Allelopathy in agroecosystems: an overview. In R. K. Kohli, H. P. Singh, \& D. R.Batish (Eds.), Allelopathy in agroecosystems (pp. 1-44). New York: Food Products Press.

Stachon, W. J., \& Zimdal, R. L. (1980). Allelopathic activity of Canada thistle (Cirsium arvense) in Colarado. Weed Science, 28, 83-86.

Swapnal, S., \& Badruzzaman, M. S. (2010). Allelopathic effect by aqueous extracts of different parts of Croton bonplandianum Baill. on some crop and weed plants. Journal of Agricultural Extension and Rural Development, 2(1), 22-28. Retrieved from http://www.researchgate.net/publication/228512918

Tongma, S., Katsuichiro, K. \& Kenji, U. (1998). Allelopathic activity of Mexican sunflower (Tithonia diversifolia) in soil. Weed Science, 46(4), 432-437.

Yang, G., Zhu, C., Luo, Y., Yang, Y., \& Wei, J. (2006). Potential allelopathic effect of Piper nigrum, Magnifera indica and Clausena lansium. Ying Yong Sheng Taixue. Bao., 17(9), 1633-1636. Retrieved from http://www.ncbi.nlm.nih.gov/pubmed/17147171

Zackrisson, O., \& Nilsson, M. C. (1992) Allelopathic effects of Empetrumherma phrodilbium on seed germination of two boreal tree species. Canadian Journal of Research, 22, 1310-1319. http://dx.doi.org/10.1139/x92-174

\section{Copyrights}

Copyright for this article is retained by the author(s), with first publication rights granted to the journal.

This is an open-access article distributed under the terms and conditions of the Creative Commons Attribution license (http://creativecommons.org/licenses/by/3.0/). 